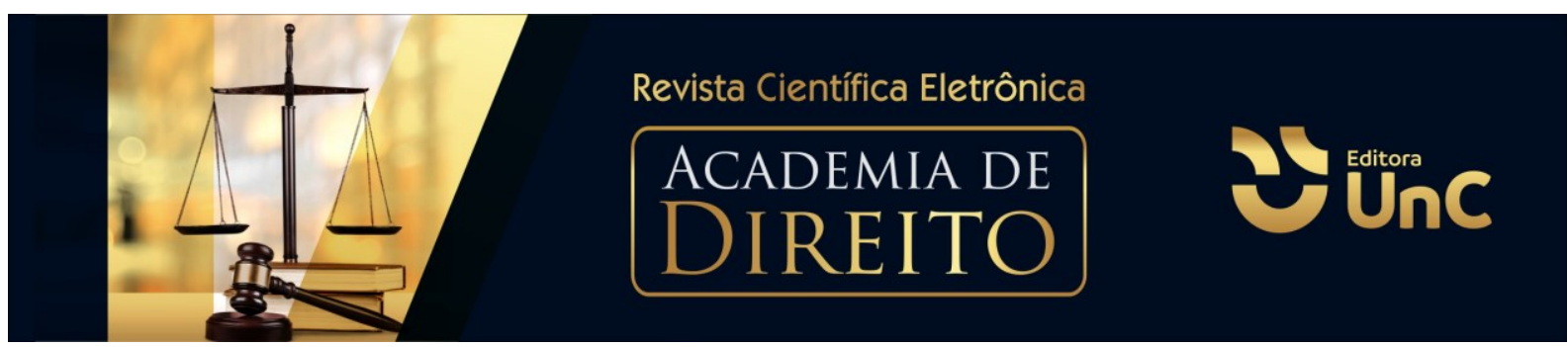

\title{
AS CAUSAS DE SUSPENSÃO DA INELEGIBILIDADE NO SISTEMA ELEITORAL BRASILEIRO E SUAS CONSEQUÊNCIAS PARA O PLEITO ELEITORAL
}

\section{THE CAUSES OF SUSPENSION OF INELIGIBILITY IN THE BRAZILIAN ELECTORAL SYSTEM AND ITS CONSEQUENCES FOR THE ELECTORAL ELECTION}

\author{
Karla Zanotelli ${ }^{1}$ \\ Cláudia Andreatta ${ }^{2}$
}

\begin{abstract}
RESUMO
O foco do trabalho recai sobre a análise das causas de suspensão de inelegibilidade elencadas pela Lei Complementar 135/2010, em seu art. 26-C, visando aprofundar o conceito e a aplicação da inelegibilidade eleitoral dos candidatos brasileiros aos cargos políticos, analisando, sobretudo, as condições de elegibilidade nos mandatos dos representantes eleitos pelo voto popular em nosso país e suas consequências para a garantia do pleito eleitoral, através de pesquisa doutrinária e jurisprudencial, em especial o julgamento do Tribunal Superior Eleitoral - RCAND n. 060090350 - que indeferiu a candidatura do ex-presidente brasileiro Luis Inácio Lula da Silva nas Eleições de 2018, o que gerou discussão sobre a (in)constitucionalidade da decisão em debate frente à aplicação da Lei da Ficha Limpa.
\end{abstract}

Palavras-chaves: Direito Constitucional. Direito eleitoral. Inelegibilidade. Lei Complementar n. 135/2010.

\begin{abstract}
The target of this work is on the analysis of the causes of suspension and ineligibility listed by the Complementary Law 135/2010, on its article 26-C, intending to deepen into the concept and the application of the electoral ineligibility of the Brazilian candidates for political positions, manly analyzing the conditions for the terms of office eligibility of the representatives elected by popular vote in our country and its consequences to guarantee the electoral system, through doctrinal and jurisprudential research, especially about the judgment of the Superior Electoral Court - RCAND $n$.

\footnotetext{
${ }^{1}$ Acadêmica do curso de Direito da Universidade do Contestado. Campus Concórdia. Concórdia. Santa Catarina. Brasil. E-mail: karla zanotelli18@hotmail.com.

${ }^{2}$ Especialista pela Universidade do Contestado. Professora do curso de Direito da Universidade do Contestado. Campus Concórdia. Seara. Santa Catarina. Brasil. E-mail:

claudiandreatta@yahoo.com.br.
} 
060090350 - which rejected the candidacy of the former Brazilian President Luis Inácio Lula da Silva in the 2018 Elections, which led to a discussion about the (un)constitutionality of this decision regarding on the application of the Clean Record Law.

Keywords: Constitutional Law. Electoral law. Ineligibility. Supplementary Law no. 135/2010.

\section{INTRODUÇÃO}

O campo do Direito Eleitoral, como ramo do direito público, é composto de normas de ordem pública, disciplinando o processo de escolha dos representantes do povo em respeito às regras do jogo democrático e assegurando a legítima escolha do cidadão.

Os sistemas eleitorais, segundo Scott Mainwaring ${ }^{3}$, envolvem detalhes que regulam uma ampla área de atuação, ordenando desde a seleção regular dos candidatos até a diplomação dos eleitos, inclusive o cálculo da distribuição das cadeiras no sistema proporcional, bem como os recursos públicos e privados possíveis de aplicação no procedimento.

Inicialmente, serão relacionados os conceitos de nacionalidade e cidadania, observando as normas constitucionais para exercer o direito de votar e ser votado.

Após, numa segunda etapa, o estudo da inelegibilidade analisará a importância do procedimento de registro de candidatura, que é um instrumento de transparência do processo eleitoral, objetivando garantir ao eleitor que os candidatos aos cargos políticos preencham os requisitos de elegibilidade previstos na Constituição Federal e possam cumprir, de forma íntegra e total, seus mandatos, sem incidir no impedimento temporário de seu direito de ser eleito.

Tem-se como objetivo desenvolver uma pesquisa acerca do atual processo eleitoral brasileiro e a aplicabilidade da Lei da Ficha Limpa e seus desdobramentos após a promulgação da Lei Complementar 135/2010. Para tanto, serão analisados os casos de inelegibilidade dos candidatos que pretendem concorrer ao pleito eleitoral,

\footnotetext{
${ }^{3}$ MAINWARING, Scott. Políticos, partidos e sistemas eleitorais: o Brasil numa perspectiva comparativa. Estudos Eleitorais, Brasília, DF, v. 1, n. 2, maio/ago. 1997, p. 335-381.
} 
com fulcro na legislação vigente e no julgado que indeferiu o registro de candidatura do ex-presidente Luis Inácio Lula da Silva na Eleição Geral de 2018.

Para a realização da pesquisa e elaboração do presente artigo, foi utilizado o método de abordagem dedutivo, aplicando a técnica de pesquisa bibliográfica, a partir de revisão doutrinária, busca em artigos científicos, bem como a análise da legislação brasileira.

\section{CIDADANIA E DIREITOS POLÍTICOS FRENTE À CAPACIDADE ELEITORAL ATIVA E PASSIVA}

Para compreender o contexto atual da sociedade no tocante ao Direito Eleitoral e suas aplicações, é necessário uma reflexão acerca dos ditames que deram origem ao conceito de democracia e, de igual forma, a ideia de cidadania apresentada como um direito-dever do cidadão no exercício da capacidade eleitoral ativa, ou seja, de escolher seus representantes políticos.

A promulgação da Constituição Federal ${ }^{4}$ de 1988 fundou um Estado Democrático de Direito, ou seja, somos um Estado que obedece as suas próprias leis e, desta forma, deve ser observada a exigência de um conjunto legislativo pautado em normas democráticas, com eleições livres, periódicas e pelo povo, bem como o respeito das autoridades públicas aos direitos e garantias fundamentais que oferecem aos cidadãos brasileiros uma segurança jurídica e social ${ }^{5}$.

Pode-se afirmar, ainda, que o Estado Democrático de Direito é composto por um sistema de garantias, que se originou de uma constituição rígida e formal, projetando uma sociedade de valores éticos e políticos centrados na dignidade da pessoa humana 6 .

Nesse contexto, importante diferenciar nacional de cidadão. O nacional é aquele que tem um vínculo jurídico com o Estado, enquanto que o cidadão tem um vínculo jurídico-político ainda mais forte, gozando de um "plus", pois tem a possibilidade de influir nos rumos do Estado através do exercício do voto.

${ }^{4}$ BRASIL. Constituição da República Federativa do Brasil de 1988.

${ }^{5}$ MORAES, Alexandre de. Jurisdição Constitucional e Tribunais Constitucionais. São Paulo: Atlas, 2000, p. 43.

${ }^{6}$ RANIERI, Nina. Teoria do Estado: do Estado de Direito ao Estado Democrático de Direito. 2.ed. São Paulo, Manole: 2019, p. 208. 
As causas de suspensão da inelegibilidade no sistema eleitoral brasileiro e suas consequências para o pleito eleitoral

A Constituição Federal, no art. $1^{\circ}$, inciso $\mathrm{II}^{7}$, prevê como fundamento da República Federativa do Brasil a cidadania que pode ser entendida como a capacidade de votar e ser votado e, como consequência, ser eleito para ocupar cargos públicos, desde que esteja em gozo dos direitos políticos ${ }^{8}$.

Premissa fundamental da democracia, os direitos políticos são consagrados nas principais declarações de direitos humanos, incluindo a Declaração Universal dos Direitos do Homem de 1948, em toda a redação de seu art. XXI9.

A própria Magna Carta, em seu art. $14^{10}$, garante direitos políticos aos nacionais qualificados como cidadãos, que tem o direito e o dever fundamental de participar direta ou indiretamente do poder estatal, realizando as escolhas dentro das regras do processo eleitoral, que são previamente estabelecidas e devem ser respeitadas durante a eleição.

\section{ELEGIBILIDADE E INELEGIBILIDADE}

A elegibilidade e a inelegibilidade são conceitos relacionados entre si. A elegibilidade são requisitos que possibilitam concorrer ao cargo público enquanto a inelegibilidade afasta essa condição.

A inelegibilidade é a perda do direito de ser votado durante um espaço determinado de tempo em razão de incidir nas condutas elencadas na LC 64/90.

As hipóteses de perda do direito de ser votado, assim como as de elegibilidade, são expressadas na Constituição Federal, contudo em seu art. 14, § $9^{011}$ atribui às

\footnotetext{
${ }^{7}$ Art. $1^{\circ}$ - A República Federativa do Brasil, formada pela união indissolúvel dos Estados e Municípios e do Distrito Federal, constitui-se em Estado Democrático de Direito e tem como fundamentos: [...] II - a cidadania;

${ }^{8}$ MORAES, Alexandre de; KIM, Richard Pae. Cidadania: o novo conceito jurídico e a sua relação com os direitos fundamentais individuais e coletivos. São Paulo, Atlas: 2013, p. 88.

${ }^{9}$ Art. XXI - I) Todo o homem tem o direito de tomar parte no governo de seu país diretamente ou por intermédio de representantes livremente escolhidos. II) Todo o homem tem igual direito de acesso ao serviço público do seu país. III) A vontade do povo será a base da autoridade do governo; esta vontade será expressa em eleições periódicas e legítimas, por sufrágio universal, por voto secreto ou processo equivalente que assegure a liberdade de voto.

${ }^{10}$ Art. 14 - A soberania popular será exercida pelo sufrágio universal e pelo voto direto e secreto, com valor igual para todos, e, nos termos da lei, mediante:

I - plebiscito;

II - referendo;

III - iniciativa popular.

${ }^{11}$ Art. 14. [...]

$\S 9^{\circ}$ - Lei complementar estabelecerá outros casos de inelegibilidade e os prazos de sua cessação, a fim de proteger a probidade administrativa, a moralidade para exercício de mandato considerada
}

Acad. Dir. (ISSNe: Em processo de criação) 
legislações complementares estabelecer outros casos de inelegibilidade. Em razão disso, foi promulgada a Lei Complementar 64/199012 (Lei das Inelegibilidades), a qual foi alterada pela Lei Complementar 135/2010 13 (Lei da Ficha Limpa).

A "Lei da Ficha Limpa", citam os doutrinadores ${ }^{14}$, trouxe como objetivo primordial o alcance do comportamento ético no sistema eleitoral em consonância com o princípio da moralidade.

Nesta mesma concepção, José Jairo Gomes ${ }^{15}$ traz uma percepção social do conceito da inelegibilidade dos candidatos, analisando que este instrumento eleitoral é capaz de defender a legitimidade das eleições, sendo destinado a proteger o funcionamento da democracia.

As inelegibilidades podem ser classificadas quanto à sua abrangência ou dimensão, podendo ser absoluta ou relativa. A primeira é a que causa impedimento para o exercício de qualquer cargo eletivo, sendo vedado ao cidadão disputar eleição. Por outro lado, a inelegibilidade relativa impede o direito do cidadão de concorrer a apenas alguns cargos ou em uma eleição específica em razão de condição pessoal ou familiar.

Em se tratando de inelegibilidade relativa, apresenta a doutrina ${ }^{16}$ que, não são consideradas genéricas, dividindo-se em diversas causas. Uma dessas causas é o motivo funcional, aplicada quando o cidadão concorre ao mesmo cargo executivo ou concorre a quaisquer outros cargos.

Outra situação encontra-se fundamentado no art. $14, \S 7^{\circ}$ da Constituição Federal ${ }^{17}$, que trata da inelegibilidade relativa por motivo de parentesco ou casamento,

vida pregressa do candidato, e a normalidade e legitimidade das eleições contra a influência do poder econômico ou o abuso do exercício de função, cargo ou emprego na administração direta ou indireta.

${ }^{12}$ BRASIL. Lei Complementar n. 64, de 18 de maio de 1990.Estabelece, de acordo com o art. 14, § $9^{\circ}$ da Constituição Federal, casos de inelegibilidade, prazos de cessação, e determina outras providências.

${ }^{13}$ BRASIL. Lei Complementar n. 135, de 4 de junho de 2010.Altera a Lei Complementar no 64, de 18 de maio de 1990, que estabelece, de acordo com o § 9o do art. 14 da Constituição Federal, casos de inelegibilidade, prazos de cessação e determina outras providências, para incluir hipóteses de inelegibilidade que visam a proteger a probidade administrativa e a moralidade no exercício do mandato.

14VASCONCELO, Clever; SILVA, Marco Antonio da. Direito eleitoral. São Paulo: Saraiva Educação, 2018, p. 71.

${ }^{15}$ GOMES, José Jairo. Direito eleitoral essencial. São Paulo: Forense, 2018, p. 66.

${ }^{16}$ VASCONCELO; SILVA. Op. Cit., p. 72.

${ }^{17}$ Art. $14[\ldots]$ $\$ 7^{\circ}$ - São inelegíveis, no território de jurisdição do titular, o cônjuge e os parentes consangüíneos ou afins, até o segundo grau ou por adoção, do Presidente da República, de Governador de Estado ou

Acad. Dir. (ISSNe: Em processo de criação) 
sendo doutriamente conhecida como "inelegibilidade reflexa", uma vez que não se resulta da condição pessoal do candidato ao pleito.

No que corresponde a extensão da inelegibilidade, 0 art. $2^{018}$ da Lei Complementar 64/1990 dispõe que, em sentido amplo compreende as hipóteses de condição de elegibilidade, já em sentido restrito refere-se às situações que the são próprias, conforme explica Gomes ${ }^{19}$.

A ocorrência da inelegibilidade pode ser atual ou superveniente, considerando o aspecto temporal. A atual se apresenta no momento em que se postula o registro de candidatura. Já a superveniente é a inelegibilidade surgida no período compreendido entre o pedido de registro de candidatura e o pleito.

Acerca da arguição das inelegibilidades, apresenta Pazzaglini ${ }^{20}$ que quando estas são constitucionais poderão ser arguidas a qualquer momento, até mesmo posterior as eleições, diferentemente das inelegibilidades infracostitucionais que devem ser suscitadas ainda na fase do registro da candidatura, sob plena de preclusão.

A inelegibilidade é denominada endógena ou exógena dependendo do local de sua ocorrência. A primeira é constituída por processo eleitoral ou em razão dele, enquanto a outra ocorre de forma exterior ao fato que ensejou o processo eleitoral.

No que se refere à elegibilidade, esta se apresenta como um direito público político subjetivo do cidadão, devendo ser averiguados todos os requisitos constitucionais para o seu exercício, os quais estão elencados na Constituição Federal ${ }^{21}$, sendo estes requisitos sempre absolutos, pois devem ser analisados para todos os candidatos em todos as disputas eleitorais.

Território, do Distrito Federal, de Prefeito ou de quem os haja substituído dentro dos seis meses anteriores ao pleito, salvo se já titular de mandato eletivo e candidato à reeleição.

${ }^{18} \mathrm{Art} .2^{\circ}$ - Compete à Justiça Eleitoral conhecer e decidir as arguições de inelegibilidade.

${ }^{19}$ GOMES. Op. Cit., p. 66.

20 PAZZAGLINI FILHO, Marino. Lei de Inelegibilidade comentada: legislação e jurisprudência atualizadas, leis da ficha limpa e da minirreforma eleitoral. São Paulo: Atlas, 2014, p. 03.

${ }^{21}$ Art. 14 [...]

$\S 3^{\circ}$ São condições de elegibilidade, na forma da lei:

I - a nacionalidade brasileira;

II - o pleno exercício dos direitos políticos;

III - o alistamento eleitoral;

IV - o domicílio eleitoral na circunscrição;

$\checkmark$ - a filiação partidária;

VI - a idade mínima [...]. 
Deste modo, aqueles que tem interesse em candidatar-se a cargo público devem preencher os requisitos de elegibilidade previstos taxativamente na carta constitucional.

Dentre esses requisitos, a nacionalidade brasileira está prevista no art. 12, incisos I e II do texto constitucional ${ }^{22}$, que permite ao brasileiro nato e naturalizado a opção de ser votado. Já o parágrafo $3^{023}$ do referido artigo, conclui que qualquer cargo eletivo é acessível a quaisquer brasileiros, com exceção os cargos para Presidente e Vice-Presidente da República, os quais são privativos de brasileiro nato, bem como a Presidência da Câmara dos Deputados e do Senado Federal.

Tal exigência se justifica, preleciona a doutrina ${ }^{24}$, porque o presidente da Câmara e do Senado, em caso de vacância ou impedimento do Presidente e de seu Vice, porem vir ser chamados a exercer a Presidência. Do mesmo modo, podendo o Presidente do Supremo Tribunal Federal vir a ser chamado a suceder ou a substituir o Presidente da República, em casos de ausência ou impedimento do Vice-Presidente e dos Presidentes da Câmara dos Deputados e do Senado Federal.

Quanto ao pleno exercício dos poderes políticos, este requisito refere-se a ausência de uma das hipóteses de perda ou suspensão de direitos políticos previstos no art. 15 da Constituição Federal ${ }^{25}$, os quais resultarão na perda de sua capacidade eleitoral passiva, isto é, a possibilidade do cidadão de ser votado.

\footnotetext{
22 Art. 12 - São brasileiros:

I - natos [...].

II - naturalizados [...].

23 Art. 12 [...]

$\S 3^{\circ}$ São privativos de brasileiro nato os cargos:

I - de Presidente e Vice-Presidente da República;

II - de Presidente da Câmara dos Deputados;

III - de Presidente do Senado Federal;

IV - de Ministro do Supremo Tribunal Federal;

$\mathrm{V}$ - da carreira diplomática;

VI - de oficial das Forças Armadas.

VII - de Ministro de Estado da Defesa.
}

24 DECOMAIN, Pedro Roberto. Elegibilidades e inelegibilidades. 2.ed. São Paulo: Dialética, 2004, p. 13.

${ }^{25}$ Art. 15. É vedada a cassação de direitos políticos, cuja perda ou suspensão só se dará nos casos de:

I - cancelamento da naturalização por sentença transitada em julgado;

II - incapacidade civil absoluta;

III - condenação criminal transitada em julgado, enquanto durarem seus efeitos;

IV - recusa de cumprir obrigação a todos imposta ou prestação alternativa, nos termos do art. $5^{\circ}$, VIII;

$\mathrm{V}$ - improbidade administrativa, nos termos do art. $37, \S 4^{\circ}$. 
As causas de suspensão da inelegibilidade no sistema eleitoral brasileiro e suas consequências para o pleito eleitoral

Ainda, o art. $11, \S 1^{\circ}$, inciso IV26 da Lei $9.504^{27}$ de 1997 , prescreve que o pleno exercício dos direitos políticos se confirmará após a emissão, pela Justiça Eleitoral, da certidão de quitação eleitoral que comprova que o cidadão cumpriu com todos as obrigações político-eleitorais.

Outro requisito é o alistamento eleitoral que concordante definição de $\mathrm{Gomes}^{28}$, trata-se do ato pelo qual a pessoa maior de 16 anos, desde que não seja estrangeiro, conscrito ou absolutamente incapaz, requer a sua inclusão nos quadros de eleitores em uma determinada circunscrição.

A Resolução 21.538/2003 do Tribunal Superior Eleitoral, em seu art. 1529, dispõe sobre a obrigatoriedade do alistamento que permite ao eleitor reunir condições de elegibilidade, isto é, capacidade de ser eleito a partir dos 18 anos de idade. Sendo que, sem o alistamento eleitoral o cidadão não pode ser votado.

No que tange ao domicílio eleitoral, este é regulado pelo parágrafo único, do art. $42^{30}$, do Código Eleitoral ${ }^{31}$. Contudo, para os casos de elegibilidade o suposto candidato deverá seguir o disposto no art. $9^{032}$ da Lei das Eleições.

A importância do domicílio eleitoral é caracterizada, principalmente, pelo fato de impedir que um candidato, nos casos de pleitos estaduais e municipais, exerça o seu mandato distante do local onde possui vínculos, o que feriria o princípio da representatividade.

Sobre o assunto escreve Gerson Gonçalves de Miranda ${ }^{33}$, que o candidato eleito é o representante dos cidadãos circunscritos em determinada região, e que em

\footnotetext{
${ }^{26}$ Art. $11[\ldots]$

$\S 1^{\circ} \mathrm{O}$ pedido de registro deve ser instruído com os seguintes documentos: [...]

VI - certidão de quitação eleitoral;

${ }^{27}$ BRASIL. Lei n. 9.504, de 30 de setembro de 1997. Estabelece normas para as eleições.

28 GOMES, Filipe Vasconcelos. A elegibilidade. Disponível em:

<https://www.boletimjuridico.com.br/doutrina/artigo/2867/a-elegibilidade>. Acesso em: 24 de mai. 2019.

${ }^{29}$ Art. 15 - O brasileiro nato que não se alistar até os 19 anos ou o naturalizado que não se alistar até um ano depois de adquirida a nacionalidade brasileira incorrerá em multa imposta pelo juiz eleitoral e cobrada no ato da inscrição.

30 Art. $42[\ldots]$

Parágrafo único. Para o efeito da inscrição, é domicílio eleitoral o lugar de residência ou moradia do requerente, e, verificado ter o alistando mais de uma, considerar-se-á domicílio qualquer delas.

31 BRASIL. Lei n. 4.737, de 15 de julho de 1965. Institui o Código Eleitoral.

32 Art. $9^{\circ}$ - Para concorrer às eleições, o candidato deverá possuir domicílio eleitoral na respectiva circunscrição pelo prazo de seis meses e estar com a filiação deferida pelo partido no mesmo prazo.

${ }_{33}$ MIRANDA, Gerson Gonçalves. Domicílio Eleitoral: uma abordagem crítica sobre domicílio eleitoral e os requisitos necessários para a sua caracterização. Disponível em:
} 
respeito ao princípio da moralidade deveria ter seu domicílio residencial coincidente com o domicílio eleitoral.

A filiação partidária é mais um dos requisitos para a elegibilidade. Regulada pela Lei 9.096/95, obriga o futuro candidato a se vincular a um partido político, já que no Brasil não é permitida a candidatura avulsa.

Conceitua o jurista José Jairo Gomes ${ }^{34}$, que por filiação compreende-se o vínculo jurídico estabelecido entre um cidadão e a entidade partidária. É regulada nos artigos 16 a 22-A da Lei 9.096/95, bem como no estatuto da agremiação política.

Para que um partido possa participar das eleições, é preciso que, 'até um ano antes do pleito, tenha registrado seu estatuto no Tribunal Superior Eleitoral', e, ainda, 'tenha até a data da convenção, órgão de direção constituído na circunscrição, de acordo com o respectivo estatuto' (LE, art. 4ㅇ). É, pois, necessário que haja sido constituído definitivamente há pelo menos um ano antes da data das eleições e, ademais, esteja regularmente instalado e em funcionamento na circunscrição do pleito que pretende disputar.

Acerca do aludido requisito, o art. $9^{\circ}$ da Lei das Eleições ${ }^{35}$, ainda prescreve a necessidade de a filiação partidária estar deferida seis meses antes da votação eleitoral.

No que tange o requisito da idade mínima para candidatar-se ao pleito eleitoral, a Constituição adotou o critério cronológico, de modo que somente ao atingir a idade especificada estará preenchida a condição de elegibilidade em apreço, podendo o cidadão submeter-se ao procedimento de registro de candidatura.

Contudo, nos termos do art. $11, \S 2^{\circ}$ da Lei 9.504/9736, ainda que a idade mínima deva ser preenchida na data do registro da candidatura, fixa-se a exceção quando o candidato ao cargo de vereador completará 18 anos na data da posse, permitindo uma excepcional deferência para essa situação.

<http://www.justicaeleitoral.jus.br/arquivos/tre-ap-artigo-1-domicilio-eleitoral>. Acesso em: 11 de jun. 2019.

${ }^{34}$ GOMES, José Jairo. Direito Eleitoral. 13a ed. São Paulo: Atlas, 2017, p. 181.

${ }^{35}$ Art. $9^{\circ}$ - Para concorrer às eleições, o candidato deverá possuir domicílio eleitoral na respectiva circunscrição pelo prazo de seis meses e estar com a filiação deferida pelo partido no mesmo prazo.

${ }^{36}$ Art. 11. Os partidos e coligações solicitarão à Justiça Eleitoral o registro de seus candidatos até as dezenove horas do dia 15 de agosto do ano em que se realizarem as eleições. [...]

$\S 2^{\circ}$ - A idade mínima constitucionalmente estabelecida como condição de elegibilidade é verificada tendo por referência a data da posse, salvo quando fixada em dezoito anos, hipótese em que será aferida na data-limite para o pedido de registro. 
Quanto a este requisito de elegibilidade, José Jairo Gomes ${ }^{37}$ abrange uma crítica pertinente: o fato de que mesmo seguindo o expresso na Constituição Federal, em determinado momento da candidatura, em que o eleito, mesmo não tendo idade compatível com o cargo, poderá assumi-lo.

\begin{abstract}
É evidente a preocupação em se exigir maior grau de consciência, experiência e maturidade dos candidatos de acordo com a importância e a complexidade das funções inerentes ao cargo. No entanto, esse desiderato pode ser frustrado na prática. Por exemplo: exige-se que o Presidente e o Vice-Presidente da República tenham, no mínimo, 35 anos; no entanto, de acordo com o artigo 80 da Constituição, em caso de impedimento ou vacância de ambos os cargos, será chamado ao exercício da Presidência da República o Presidente da Câmara dos Deputados, cuja idade poderá ser de 21 anos. O mesmo ocorre com Governadores e Prefeitos, que poderão ser substituídos por Deputado Estadual ou Vereador com idade de 21 e 18 anos, respectivamente.
\end{abstract}

Além dos requisitos exigidos pela Magna Carta, a Lei 9.504/97, que estabelece as normas para as eleições, dispõe em seu art. $11, \S 10^{\circ 38}$ que as condições de elegibilidade devem ser demonstradas no momento da formalização da candidatura.

Existem os requisitos positivos que estão previstos de forma implícita na Constituição Federal e também pressupostos negativos que não devem estar presentes quando do registro de candidatura, como a inelegibilidade a qual está disposta na Lei Complementar 64/90.

O entendimento jurisprudencial do colendo Tribunal Superior Eleitoral, determina ainda, que as condições de elegibilidade devem estar preenchidas no momento do registro da candidatura. Neste sentido, se após o decurso deste prazo for constatada alguma causa de inelegibilidade, o pedido há de ser indeferido ${ }^{39}$.

Contudo, é possível que após o deferimento do registro de candidatura pela Justiça Eleitoral, o candidato venha a ser condenado criminalmente, por ação de improbidade administrativa ou, ainda, uma condenação pelo Tribunal de Contas por conduta ocorrida em cargo anteriormente ocupado.

37 GOMES. Op. Cit., p. 183.

${ }^{38}$ Art. $11[\ldots]$

$\S 10^{\circ}$ - As condições de elegibilidade e as causas de inelegibilidade devem ser aferidas no momento da formalização do pedido de registro da candidatura, ressalvadas as alterações, fáticas ou jurídicas, supervenientes ao registro que afastem a inelegibilidade.

39 DECOMAIN. Op. Cit., p. 11. 
Neste sentido, trataremos sobre as implicações da condenação em processo criminal após o deferimento do registro e antes da data do pleito.

\section{A SUSPENSÃO DA INELEGIBILIDADE SOB A ÉGIDE DA LEI COMPLEMENTAR 135/2010 E O ART. 26-C}

Com o advento da LC 135/2010, que alterou a LC 64/1990, foi ampliado o rol de inelegibilidades. Assim, muitos dos ilícitos eleitorais e crimes contra a administração pública passaram a gerar inelegibilidades a serem aplicadas nas eleições subsequentes, o que ampliou a aplicação da LC 64/90 e levantou questionamentos acerca da constitucionalidade e do momento de sua aplicação.

Nessa linha, foram ajuizadas três ações no Supremo Tribunal Federal (ADCs n. 29, n. 30 e a ADI n. 4.578) e, por maioria de votos, a LC 135/2010 foi declarada constitucional e reconhecida sua aplicabilidade imediata, ou seja, aplicável já nas eleições do ano de 2010, alcançando fatos anteriores a sua vigência.

Ainda, além da Lei apresentar novas hipóteses de suspensão dos direitos políticos, aumentou os prazos de inelegibilidades previstos na Lei Complementar 64/90 de 03 (três) para 08 (oito) anos, conforme preceitua o art. $1^{\circ}$, inciso I, alínea $\mathrm{e}^{40}$. Dessa forma, sua vigência tinha o objetivo de privar os candidatos que não apresentavam conduta ilibada de exercer cargo público eletivo.

Das inelegibilidades surgidas por intermédio da Lei Complementar 135/2010, é possível que a inelegibilidade ocorra após o deferimento do registro de candidatura e antes do pleito eleitoral. Neste caso, ela deve ser reconhecida e aplicada ou deve ser afastada porque preclusa dentro do procedimento de registro?

Nesse caso bastante específico, se o candidato condenado em segunda instância de julgamento, nos exatos termos do art. $26-C^{41}$, o registro de candidatura,

\footnotetext{
${ }^{40}$ Art. $1^{\circ}$ - São inelegíveis:

I - para qualquer cargo: [...]

e) os que forem condenados, em decisão transitada em julgado ou proferida por órgão judicial colegiado, desde a condenação até o transcurso do prazo de 8 (oito) anos após o cumprimento da pena, pelos crimes [...]

${ }^{41}$ Art. 26-C - O órgão colegiado do tribunal ao qual couber a apreciação do recurso contra as decisões colegiadas a que se referem as alíneas $d, e, h, j, I$ e $n$ do inciso I do art. $1^{\circ}$ poderá, em caráter cautelar, suspender a inelegibilidade sempre que existir plausibilidade da pretensão recursal e desde que a providência tenha sido expressamente requerida, sob pena de preclusão, por ocasião da interposição do recurso.
} 
As causas de suspensão da inelegibilidade no sistema eleitoral brasileiro e suas consequências para o pleito eleitoral

ainda que deferido, deve ser cassado, visto que o registro de candidatura apenas emite um juízo circuntancial da situação do candidato. Ainda, se a inelegibilidade surgida desta condenação em $2^{\circ}$ grau ofende diretamente a Constituição Federal, não é possível que o então candidato dispute a eleição.

Anteriormente ao julgamento do HC 84.078/MG pelo Supremo Tribunal Federal, nos moldes do art. 15 , inciso III da $\mathrm{CF}^{42}$, a suspensão do direito só era possível após o trânsito em julgado da sentença penal condenatória - questão que voltou ao plenário da Corte em outubro de 2019.

Ao observar a sistemática do processo eleitoral, em especial após o deferimento do registro de candidatura, percebe-se que a Justiça Eleitoral prima pela lisura do processo eleitoral através da verificação de todos os requisitos e pressupostos dos candidatos que concorrem, em especial o atendimento a plena capacidade eleitoral passiva.

Neste viés, a Lei da Ficha limpa, em seu art. 26-C, garantiu aos candidatos o direito de ser votado quando ainda há uma possibilidade de reforma da decisão condenatória. Nesta linha, enquanto não transitada em julgado a decisão condenatória, o candidato poderá seguir com sua campanha e, inclusive, poderá ser eleito e diplomado, desde que seja deferida medida cautelar.

Neste sentido, já julgou o Superior Tribunal Eleitoral:

\begin{abstract}
ELEIÇÕES 2012. REGISTRO DE CANDIDATURA. VEREADOR. INDEFERIMENTO. CONDENAÇÃO POR ATO DOLOSO DE IMPROBIDADE ADMINISTRATIVA. INELEGIBILIDADE. ART $1^{\circ}$, INCISO I, ALÍNEA L, DA LC $\mathrm{N}^{\circ}$ 64/90. SUSPENSÃO. ART. 26-C DA LC No 64/90. 1. O candidato obteve, nos termos do art. 26-C da LC no 64/90, provimento liminar proferido pelo Presidente da Seção de Direito Público do TJSP o qual sustou os efeitos da decisão que o condenou à suspensão dos direitos políticos por ato doloso de improbidade administrativa, razão pela qual não incide a causa de inelegibilidade prevista na alínea 'l' do inciso I do art. $1^{\circ}$ da LC no 64/90. 2. Este Tribunal, ao apreciar a questão de ordem na Ação Cautelar $n^{\circ} 1.420$ 85 , definiu que a regra do art. $26-C$, caput, da $L C n^{\circ} 64 / 90$ - a qual estabelece que o órgão colegiado do tribunal competente poderá suspender, em caráter cautelar, a inelegibilidade - não exclui a possibilidade de o relator, monocraticamente, decidir as ações cautelares que lhe são distribuídas. 3 . Tal entendimento foi reafirmado no julgamento do Respe no 527-71/SP, Rel. Min. Dias Toffoli, PSESS em 13.12.2012, ao se assentar que 'a concessão de efeito suspensivo pelo Presidente da Seção de Direito Público do Tribunal de Justiça ao recurso especial interposto contra o acórdão do TJ que manteve
\end{abstract}

\footnotetext{
${ }^{42}$ Art. 15. É vedada a cassação de direitos políticos, cuja perda ou suspensão só se dará nos casos de: $[\ldots]$

III - condenação criminal transitada em julgado, enquanto durarem seus efeitos;
} 
a condenação por improbidade administrativa é apto para suspender a inelegibilidade, a teor do art. $26-\mathrm{C}$ da LC no 64/90'. 4. De igual modo, esta Corte também já julgou que, 'independentemente de a questão ter sido tratada expressamente na decisão liminar', seria possível afastar a inelegibilidade nos termos do art. 26-C da LC n 64/90 (AgREs- pe $n^{\circ} 687-$ 67/SP, da relatoria do Ministro Arnaldo Versiani, PSESS no dia 30.10.2012). Agravo regimental a que se nega provimento. ${ }^{43}$

Contudo, exitem decisões judiciais que vedam tal possibilidade, afirmando que o candidato condenado por órgão colegiado, quando não caiba recurso com efeito suspensivo, deve ser afastado da disputa eleitoral - foi o que ocorreu com o candidato Luis Inácio Lula da Silva em 2018 (TSE - RCAND n. 060090350).

No caso em comento, o candidato acima nominado não pode participar do pleito eleitoral, uma vez que o entendimento do Tribunal Superior Eleitoral, pelo voto de seis dos sete ministros que compõe a Corte, nos termos do voto do Relator, Min. Luís Roberto Barroso, sustentou a aplicação do enunciado de súmula $41^{44}$ do Tribunal Superior Eleitoral.

Tendo em vista a redação do art. 26-C da Lei Complementar 64/1990, o Órgão Colegiado não determinou a suspensão da inelegibilidade em caráter cautelar no caso do Ex-Presidente Lula, o que impediu que o então candidato participasse das Eleições Presidenciais do ano de 2018, mas permitisse à Coligação sua substituição.

Ressalta-se que o Comitê de Direitos Humanos da Organização das Nações Unidas apresentou manifestação na qual defendeu a elegibilidade do candidato em face do não transito em julgado da decisão condenatória. Contudo, o relator, afastando o argumento afirmando que a Justiça Eleitoral não se obriga à determinação emitida pelo Órgão Internacional.

Assim, o ministro-relator votou pelo retirada do candidato da disputa eleitoral em razão de condenação em $2^{\circ}$ grau por lavagem de dinheiro e corrupção, sob a égide da Lei da Ficha Limpa ${ }^{45}$ :

[...] diante (i) da incidência da causa de inelegibilidade prevista no art. $1^{\circ}, \mathrm{I}$, alínea e, itens 1 e 6, da LC no 64/1990, com redação dada pela Lei da Ficha Limpa; (ii) da impossibilidade de dar cumprimento à medida cautelar expedida pelo Comitê de Direitos Humanos da ONU, pelos fundamentos acima; e (iii)

\footnotetext{
${ }^{43} \mathrm{AgR}$-REspe $\mathrm{n}^{\circ}$ 28.152, Rel. Min. Henrique Neves da Silva, DJE 13.5.2013.

44 "Não cabe à Justiça Eleitoral decidir sobre o acerto ou desacerto das decisões proferidas por outros órgãos do Judiciário ou dos tribunais de contas que configurem causa de inelegibilidade".

${ }^{45}$ REGISTRO DE CANDIDATURA (11532) n. 0600903-50.2018.6.00.0000 - Brasília - Distrito Federal. Relator Ministro Luís Roberto Barroso.
} 
da improcedência de todas as demais teses de defesa, voto pela procedência das impugnações formuladas e pelo reconhecimento da incidência da causa de inelegibilidade informada nas notícias de inelegibilidade. Como consequência, indefiro o pedido de registro de candidatura do candidato Luiz Inácio Lula da Silva ao cargo de Presidente da República nas eleições de 2018.

O voto divergente, proferido pelo Min. Edson Fachin, defendeu a garantia ao candidato-requerente, mesmo estando preso, de concorrer às eleições. Isto porquê o Comitê da Organização das Nações Unidas concedeu uma medida provisória para que o requerente pudesse desfrutar dos seus direitos políticos como candidato ao cargo de Presidente da República, votando então, a favor do deferimento do registro de candidatura de Luis Inácio Lula da Silva.

O Min. Jorge Mussi, por sua vez, reforçou a constitucionalidade da Lei da Ficha Limpa, afirmando que o processo eleitoral deve seguir os parâmetros da justiça e dos princípios democráticos. Neste viés, para alcançar o objetivo almejado, faz-se necessário que as eleições sejam disputadas por candidatos que atendam aos requisitos constitucionais e legais.

O Min. Og Fernandes pontuou a controvérsia do fato da Organização das Nações Unidas (ONU) recomendar que a candidatura do ex-presidente Luis Inácio Lula da Silva prosperasse, questionando a força normativa da posição internacional frente ao processo eleitoral brasileiro.

Ao julgar o mérito da causa, o ministro Admar Gonzaga ponderou o papel da Justiça Eleitoral nos processos de candidaturas, pautando-se no Enunciado de Súmula 41 do Tribunal Superior Eleitoral. Nessa linha, defendeu:

Portanto, ao apreciar o requerimento de registro de candidatura e eventual ação de impugnação, não cabe à Justiça Eleitoral se manifestar acerca do mérito dos fatos ensejadores da inelegibilidade. A competência se restringe a examinar a adequação do pretenso candidato às regras constitucionais e infraconstitucionais alusivas à elegibilidade, tomando como base suporte fático-jurídico já consolidado, não mais sujeito à pesquisa no âmbito do processo de registro de candidatura. ${ }^{46}$

${ }^{46}$ REGISTRO DE CANDIDATURA (11532) n. 0600903-50.2018.6.00.0000 - Brasília - Distrito
Federal. Relator Ministro Luís Roberto Barroso. 
Em seu voto, o ministro acompanha o relator, indeferindo o registro de candidatura de Luis Inácio Lula da Silva ao cargo de Presidente da República, em razão da incidência de inelegibilidade prevista na Lei Complementar 64/90.

Tarcísio Vieira de Carvalho Neto, o quinto ministro à proferir seu voto, também entendeu pelo indeferimento do registro pleiteado, baseando-se no que dispõe o art. $1^{\circ}$, inciso I, alínea e, 1 e $6^{47}$, da Lei de inelegibilidades.

A presidente do Tribunal Superior Eleitoral, Min. Rosa Weber, acolheu os pedidos de indeferimento do registro de candidatura do ex-presidente Luis Inácio Lula da Silva, mas assegurou a realização de todos os atos de campanha enquanto perdurar a sua condição sub judice.

Diante desta colocação da Ministra Presidente, o relator já havia se posicionado no seguinte sentido:

\footnotetext{
Verificada a incidência de causa de inelegibilidade, deve-se reconhecer a inaptidão do candidato para participar das eleições de 2018 visando ao cargo de Presidente da República. Para afastar a inelegibilidade prevista no art. $1^{\circ}$, I, alínea "e", da LC n 64/1990, seria necessário, nos termos do art. 26-C da LC n ${ }^{\circ} 64 / 1990$, que o órgão colegiado do tribunal ao qual couber a apreciação do recurso contra a decisão do TRF da $4^{\mathrm{a}}$ Região suspendesse, em caráter cautelar, a inelegibilidade, o que não ocorreu no caso.
}

Portanto, diante da decisão plenária do Tribunal Superior Eleitoral, o art. 26-C, incorporado à legislação brasileira através da Lei Complementar 135/2010, reconhecidamente constitucional, é aplicável ao caso do ex-presidente Luis Inácio Lula da Silva e à outros processos de cunho eleitoral que visam a verificação da inelegibilidade, somente sendo afastada quando o Poder Judiciário deferir medida cautelar em decorrência da plausibilidade do direito alegado.

Indubitávelmente, a jurisprudência majoritária reconhece que a aplicação da LC $135 / 2010$ tem sido efetiva e se justifica na garantia da legitimidade do processo eleitoral.

\footnotetext{
${ }^{47}$ Art. $1^{\circ}$ - São inelegíveis:

I - para qualquer cargo: [...]

e) os que forem condenados, em decisão transitada em julgado ou proferida por órgão judicial colegiado, desde a condenação até o transcurso do prazo de 8 (oito) anos após o cumprimento da pena, pelos crimes:

1. contra a economia popular, a fé pública, a administração pública e o patrimônio público; [...]

6. de lavagem ou ocultação de bens, direitos e valores;
} 


\section{CONSIDERAÇÕES FINAIS}

A Lei da Ficha Limpa trouxe ao ordenamento jurídico maior segurança e rigor na verificação das inelegibilidades, protegendo a probidade administrativa e a moralidade.

Neste sentido, as decisões proferidas pelo Poder Judiciário Brasileiro, relacionadas à elegibilidade ou inelegibilidade dos candidatos ao pleito eleitoral, que ocorreram após a promulgação da LC 135/2010, em tudo obedeceram às normas constitucionais, permitindo que o eleitor e o candidato exerçam seus direitos e comprometam-se com um justo processo democrático.

Diante disto, a Justiça Eleitoral brasileira, no julgamento do pedido de registro do candidato e ex-presidente brasileiro, Luis Inácio Lula da Silva, demonstrou retidão e comprometimento com a lei da ficha limpa, demonstrando à sociedade a lisura aplicada em seus processos, em especial aos registros de candidaturas, sem dirimir sob qualquer hipótese a legislação vigente, uma vez que a democracia e a igualdade social dependem também de candidatos aptos a governar o povo brasileiro.

Ainda sobre a importância da referida lei, bem como a jurisprudência relacionada aos procedimentos de registro de candidatura, demonstram a transparência da Justiça Eleitoral na aplicação das determinações constitucionais quando afasta da possibilidade de exercer cargos públicos àqueles que não preenchem as condições necessárias de elegibilidade ou quando incorrem em condições de inelegibilidade.

Ademais, no procedimento de registro, percebe-se que o art. 26-C da lei de Eleições é uma norma que permite corrigir equívocos quando houver plausibilidade do direito alegado, afastando a causa de inelegibilidade por análise criteriosa do Poder Judiciário.

Portanto, a validade da Lei da Ficha Limpa (LC 135/2010) no âmbito jurídico e social é inderrogável, já que preenche todos os preceitos e normas expressos na Constituição Federal de 1988 e, ainda, assume importante papel instrumental no Estado Democrático de Direito, corroborando a integridade do sistema eleitoral e combatendo a corrupção eleitoral no país. 


\section{REFERÊNCIAS}

BRASIL. Constituição da República Federativa do Brasil de 1988.

BRASIL. Lei Complementar n. 64, de 18 de maio de 1990. Estabelece, de acordo com o art. 14, $\S 9^{\circ}$ da Constituição Federal, casos de inelegibilidade, prazos de cessação, e determina outras providências.

BRASIL. Lei Complementar n. 135, de 4 de junho de 2010. Altera a Lei Complementar no 64, de 18 de maio de 1990, que estabelece, de acordo com o § 9o do art. 14 da Constituição Federal, casos de inelegibilidade, prazos de cessação e determina outras providências, para incluir hipóteses de inelegibilidade que visam a proteger a probidade administrativa e a moralidade no exercício do mandato.

BRASIL. Lei n. 4.737, de 15 de julho de 1965. Institui o Código Eleitoral.

BRASIL. Lei n. 9.504, de 30 de setembro de 1997. Estabelece normas para as eleições.

DECOMAIN, Pedro Roberto. Elegibilidades e Inelegibilidades. 2.ed. São Paulo: Dialética, 2004.

FILHO, Marino Pazzaglini. Lei de inelegibilidade comentada: legislação e jurisprudência atualizadas, leis da ficha limpa e da minirreforma eleitoral. São Paulo: Atlas, 2014.

GOMES, Filipe Vasconcelos. A elegibilidade. Disponível em:

<https://www.boletimjuridico.com.br/doutrina/artigo/2867/a-elegibilidade>.

GOMES, José Jairo. Direito eleitoral. 13.ed. São Paulo: Atlas, 2017.

GOMES, José Jairo. Direito eleitoral essencial. São Paulo: Forense, 2018.

MAINWARING, Scott. Políticos, partidos e sistemas eleitorais: o Brasil numa perspectiva comparativa. Estudos Eleitorais, Brasília, DF, v. 1, n. 2, maio/ago. 1997.

MIRANDA, Gerson Gonçalves. Domicílio eleitoral: uma abordagem crítica sobre domicílio eleitoral e os requisitos necessários para a sua caracterização. Disponível em: <http://www.justicaeleitoral.jus.br/arquivos/tre-ap-artigo-1-domicilio-eleitoral>.

MORAES, Alexandre de. Jurisdição constitucional e tribunais constitucionais. São Paulo: Atlas, 2000.

MORAES, Alexandre de; KIM, Richard Pae. Cidadania: o novo conceito jurídico e a sua relação com os direitos fundamentais individuais e coletivos. São Paulo, Atlas: 2013. 
RANIERI, Nina. Teoria do Estado: do estado de direito ao estado democrático de direito. 2.ed. São Paulo: Manole: 2019.

VASCONCELO, Clever; SILVA, Marco Antonio da. Direito eleitoral. São Paulo: Saraiva Educação, 2018.

Artigo recebido em: 11/12/2019

Artigo aceito em: 13/12/2019

Artigo publicado em: 11/05/2020 